\title{
EKSPLOITASI ANAK DI KOTA LAYAK ANAK (STUDI DI KOTA KENDARI)
}

\author{
Hadi Machmud \\ Institut Agama Islam (IAIN) Kendari \\ Email: machmud657@gmail.com
}

\author{
Nur Alim \\ Institut Agama Islam (IAIN) Kendari \\ Email: nuralimbasri@gmail.com \\ Rasmi \\ Institut Agama Islam (IAIN) Kendari \\ Email: rasmigazali18@gmail.com
}

\begin{abstract}
Abstrak
Artikel ini bertujuan untuk mengurai ketimpangan sosial dan tuntutan kebutuhan ekonomi yang terjadi di kota Kendari sehingga memicu munculnya eksploitasi pada anak. Permasalahan penelitian adalah; (1) Bagaimanakah bentuk eksploitasi dan dampak sosial, ekonomi, kesehatan, psikologi dan pendidikan, pada anak di Kota Kendari, (2) Bagaimana upaya pemerintah mencegah eksploitasi anak di kota Kendari. Penelitian menggunakan metode kualitatif studi kasus, mengumpulkan data dengan menggunakan teknik observasi, wawancara, dokumentasi. Hasil penelitian; (a) Terjadinya eksploitasi anak dipengaruhi oleh ekonomi keluarga, kemiskinan, komunitas, pengaruh lingkungan, keretakan, kekerasan kehidupan rumah tangga, perceraian orang tua, (b) Bentuk eksploitasi anak dilakukan oleh orang tua dan preman berupa pekerja anak; menjadi pemulung, tukang pikul, penjual tisu, peminta/pengemis di lampu merah, penjajah makan ringan, menjadi buruh, (c) Dampak terjadinya eksploitasi anak meliputi; ekonomi, sosial, kesehatan, psikologis, pendidikan, kehidupan bermasyarakat, anak putus sekolah, kenakalan, berkelahi, perilaku menyimpang secara social, merokok, miras, menjudi, hidup bersama beberapa orang dengan laki-laki dan perempuan dalam satu kamar kosan, hidup tidak terawat. (d) Program pemerintah Kota Kendari mencegah, mengeliminir eksploitasi anak; mengoptimalkan implementasi program pemerintah Kementerian Pemberdayaan Perempuan dan Perlindungan anak, Nota Kesepahaman Bersama (MOU) antara Pemerintah Pusat dengan Pemerintah Kota Kendari, mengukuhkan Asosiasi Pengusaha Sahabat Anak Indonesia (APSAI) Kendari, pelibatan OPD, Psikolog, BUMN, LSM dan masyarakat.
\end{abstract}

Kata Kunci: Eksploitasi, Anak, Kota Layak Anak. 


\begin{abstract}
This article aims to outline the inequality and the complex life demands in social and economic life which trigger various problems in the lower middle-class society leading to the child exploitation. The research problems of this study are (1) what kind of exploitation experienced by children in Kendari and what is the impact of the children exploitation on social, economic, health, psychology and education life?, and (2) How is the Government's effort to prevent the children exploitation in Kendari as a child-friendly city?. This research uses a qualitative research method with a case study of children in Kendari. The data were collected by using observation, interview, and documentation techniques. The results indicate that; (1) the main causes of child exploitation in Kendari are poverty, community and environmental influences, fractures, domestic violence, and parents' divorce, (2) some kinds of exploitation in Kendari are those done by parents and a group of thugs to make the children work as laborers; such as things carrier in the market, street vendors who sell almost anything, beggars in the traffic light, and so on (3) The impact of exploitation on children can include several things namely: economic, social, health, psychological and educational impact while the impact of exploitation of children in social life, such as children may drop out of school, do delinquency, fight, do socially abusive behavior such as; smoking, drinking, gambling, living with several people with men and women in one rented room, and living without any rules. (4) The program carried out by the government to prevent and eliminate the children exploitation in Kendari as Child-Friendly City is to improve the government program through the Ministry of Women's Empowerment and Child Protection which is currently being promoted, namely the Child-Friendly City (KLA). The Memorandum of Understanding (MOU) between the Central Government and Kendari results in the establishment of the Association of Indonesian Child Friendly Employers (APSAI) Kendari. Besides, the government needs to embrace several Regional Work Units (SKPD) or OPD, Psychologists, SOEs, NGOs and the community to work on this issue together.
\end{abstract}

Keywords: Exploitation, Children, Child-Friendly city.

\title{
Pendahuluan
}

Indonesia merupakan negara yang menempatkan kepentingan anak dengan pemenuhan dan pemberian hak-hak pada anak serta ikut medeklarasikan "World Fit for Children" pada tanggal 20 Vovember 1989 di Amerika Serikat. Atas dasar deklarasi inilah kemudian pada tahun 2006 pemerintah menindak lanjuti melalui Kementerian Pemberdayaan Perempuan dan Perlindungan Anak (KPP-PA) dengan membentuk dan mengembangkan Kota Layak Anak (KLA), dengan Peraturan nomor 12 tahun 2011 tentang Indikator Kabupaten/Kota Layak Anak. Kota Layak Anak merupakan sistem pembangunan Kabupaten/Kota yang mengintegrasikan komitmen dan sumber daya pemerintah, masyarakat dan dunia usaha yang terencana secara menyeluruh dan berkelanjutan dalam kebijakan, program dan kegiatan untuk pemenuhan hak-hak anak. 
Pada tahun 2019 di Kota Makassar Sulawesi Selatan. Menteri Pemberdayaan Perempuan dan Perlindungan Anak memberikan penghargaan Kabaupaten/Kota Layak Anak kepada 135 Kabupaten/Kota yang meraih predikat Pratama, 86 meraih predikat Madya, dan 23 meraih predikat Nindya (2019:2). Substansi program Kota Layak Anak adalah terciptanya Kota/Kabupaten dimana anak dapat tumbuh kembang secara optimal dan terlindungi dari kekerasan dan diskriminasi. Program KLA yang gencar dilaksanakan pemerintah sebagai wujud menciptakan dan mewujudkan Child Friendly Country sebagai penegasan Konvensi Hak Anak (KHA) bahawa profil anak disesuaikan dengan lima kluster Hak Anak, yakni; (1) Hak sipil dan kebebasan; (2) lingkungan keluarga dan pengasuhan alternatif; (3) kesehatan dasar dan kesejahtraan; (4) pendidikan, pemanfaatan waktu luang dan kegiatan budaya; (5) perlindungan khusus (Maidin Gultom; 2008: 33).

Studi tentang Eksploitasi anak di Kota Layak Anak telah dilakukan ditataran regional oleh beberapa peneliti antara lain; (Nenik Yuniarti; 2012; Eksploitasi Anak Jalanan Sebagai Pengamen dan Pengemis di Terminal Tidar Oleh Keluarga; Andriani Elisabeth \& Zainul Hidayat; 2018; Implementasi Program Kota Layak Anak dalam Upaya Pemenuhan Hak-Hak Anak di Kota Bekasi; Beta S. Iryani, dkk; 2013; Eksploitasi terhadap Anak yang Bekerja di Indonesia; Tjandraningsih dan Popon Anarita; 2002; Pekerja Anak di Perkebunan Tembakau, Yayasan Akatiga; Darmini Roza dan Laurensius Arliman S Peran; 2017 Pemerintah Daerah dalam mewujudkan Kota Layak Anak di Indonesia; Boby Novika; 2018; Optimalisasi Pelaksanaan Kebijakan Pengembangan Kota Layak Anak dan Implementasinya Terhadap Ketahanan Sosial Masyarakat; Ld.Muhammad Elwan; 2018; Rekomendari Kebijakan Program Kota Layak Anak di Kota Kendari).

Kota Kendari merupakan salah satu Kota Layak Anak (KLA) yang ditetapkan pemerintah dan telah mendaptkan penghargaan sebagai kota Layak Anak kategori Tingkat Madya. Penerapan dan penetapan Kota Kendari sebagai kota ramah anak merupakan realisasi program pemerintah dan amanah undang-undang, dimana tujuan dan sasaran mengutamakan kepentingan anak, resfek dan berafiliasi pada kebutuhan dan kesejahteraan anak. Keberhasilan pemerintah Kota Kendari meraih berbagai penghargaan, ternyata tidak sepenuhnya dirasakan oleh anak-anak, hal ini dikarenakan masih ditemukan beberapa kasus eksploitasi pada anak-anak, terutama anak yang tidak mampu secara ekonomi dan sosial. Kota kendari memiliki data pekerja anak dan anak 
jalanan di sektor jasa yang berusia dibawah 18 tahun, sedangkan yang tidak terdata bahkan lebih banyak lagi anak yang bekerja membantu keluarga/orang tua mencari nafkah memenuhi kebutuhan hidup. Dampak anak yang bekerja berakibat pada hilangnya hak-hak kebebasan belajar, bermain dan mengembangkan potensi, mereka tidak dapat mengenyam pendidikan seperti layaknya anak-anak yang lain. Penyelenggaraan perlindungan anak berasaskan Pancasila dan berlandaskan UUD NRI Tahun 1945 serta prinsip-prinsip dasar Konvensi Hak-hak Anak (KHA) meliputi, asas non diskriminasi, asas kepentingan yang terbaik bagi anak, asas hak untuk hidup, kelangsungan hidup dan perkembangan, dan asas penghargaan terhadap pendapat anak (Imran Jauhari; 2013:612).

Anak jalanan dan pekerja anak di Kota Kendari merupakan salah satu masalah sosial yang terdapat dalam masyarakat. Masalah sosial terjadi ketika status sosial seseorang terganggu dan fungsi sosial tidak berjalan dengan baik serta hal ini berkaitan dengan peran yang hilang atau malah dihilangkan. Anak jalanan dan pekerja anak sebagai masalah sosial dikarenakan mereka telah kehilangan hak tumbuh kembang layak dan hak sekolah mendapatkan pendidikan, dimana pada masa itu seharusnya mereka mendapatkan pendidikan, pengajaran dan mengisi diri dengan kegiatan yang mendukung pengembangan diri ke depan, namun mereka harus bekerja mencari nafkah membantu orang tua, keluarga untuk memenuhi kebutuhan hidup. Saeful Saleh \& Muh. Nur (2016) menjelaskan bahwa bagi orang miskin anak pada umumnya memiliki fungsi ekonomi, menjadi salah satu sumber pendapatan, penghasilan keluarga sehingga anak sudah biasa sejak usia dini dilatih, dipersiapkan untuk menghasilkan uang. Eksploitasi yang sering dialami oleh anak dilakukan oleh keluarga tanpa memperhatikan hak-hak, perlindungan dan perkembangan pisik, psikhis dan status sosial anak.

Berdasrkan urian di atas maka penelitian ini diakukan untuk mengetahui ketimpangan, tuntutan kebutuhan hidup yang kompleks dalam kehidupan sosial ekonomi yang pada akhirnya memicu munculnya permasalahan pada masyarakat menengah kebawah yang bermuara pada terjadinya eksploitasi pada anak. Secara spesfik penelitian bertujuan untuk mengetahui; (1) Bagaimanakah bentuk eksploitasi dan dampak sosial, ekonomi, kesehatan, psikologi dan pendidikan, pada anak di Kota Kendari, (2) Bagaimana upaya Pemerintah mencegah eksploitasi anak di kota Kendari. 


\section{Metode Penelitian}

Berdasarkan latar belakang dan permasalahan penelitian, maka pemilihan metode penelitian mengacu pada data kualitatif berdasarkan perspektif relasi kehidupan sosial dan ekonomi anak dari kelurga yang terteliti. Pengumpulan dan pengelohan data dilakuan dengan teknik berjenjang dan berkelanjutan (multistage dan multilevel). Teknik yang dipakai meliputi; (1) wawancara dilakukan secara tidak formal, kunjungan ke rumah, ketempat sumber data, dan ditempat anak-anak bekerja, berdialog dengan subjek atau tempat lain dimana keterlibatan peneliti bisa dikembangkan, (2) observasi dilakukan untuk memperoleh informasi tentang eksploitasi anak, pekerjaan yang dilakukan setiap anak, hubungan sosial, dan kegiatan sehari-hari dalam keluarga dan masyarakat dengan mengamati secara langsung dengan dukungan data dokumentasi.

Analisis data dimulai sejak pengumpulan data, dari data yang disampaikan oleh setiap informan, divalidasi melalui komentar informan yang berbeda. Analisis dilakukan melalui sebuah proses penyeleksian yang ketat atas data, selanjutnya dilakukan klasifikasi, penyimpulan serta uji ulang. Data yang terkumpul disaring dan diklasifikasi dalam berbagai kategori, kemudian dihubungkan antara satu dan yang lainnya. Tujuannya adalah untuk memperkokoh dan memperluas bukti yang akan dijadikan dasar bagi pengambilan kesimpulan. Pengujian dan pemaknaan dilakukan berdasarkan pendekatan fenomenologi. Langkah yang ditempuh adalah; (a) permasalahan dan perumusan pertanyaan penelitian, (b) data yang menghasilkan situasi teks pengalaman kehidupan, (c) hasil kategorisasi yang dilakukan pada tahap dua digambarkan dalam bentuk narasi. (d) reduksi data, (e) analisa data melalu; penerjemahan, penafsirandengan melakukan interpretasi teks yang melekat pada sistem eksploitasi anak, pembacaan kemudian, (e) mengambil kesimpulan, hasil dari intrepretasi terhadap data dinarasikan sebagai temuan penelitian.

\section{Kajian Teori}

Suatu penelitian membutuhkan kajian teori sebagai landasan teori atau konsep dari pendapat beberapa ahli, tokoh dan pakar, untuk menuntun peneliti terutama dalam menganalisis data, berikut dijelaskan beberapa kajian literatur penyusunan artikel ini:

\section{Eksploitasi Anak}


Nuraeny Hilman (2017) mendefinisikan eksploitasi anak sebagai kejahatan social yang memiliki dampak panjang dan menghancurkan anak, keluarga, penyelidik dan masyarakat. Eksploitasi anak merampok masa kecil korban sekaligus mengganggu perkembangan emosional dan psikologis mereka. Eksploitasi anak terdiri dari kriminal anak yang hilang, pelecehan seksual, dan bentuk lain dari pemanfaatan anak untuk keperluan komersial. Masalah eksploitasi anak tidak bisa dilepaskan dari tantangan teknis dan masalah sosial yang perlu ditangani secara bersamaan dengan kemungkinan penggunaan teknologi informasi dan komunikasi sebagai perlindungan. Allsup, R., Thomas, E., Monk, B., Frank, R., \& Bouchard, M. (2015). Menjelaskan bahwa dari perspektif penegakan hukum, pemahaman topografi dan strategi gangguan jaringan eksploitasi anak online memiliki nilai yang signifikan karena dapat merinci cara terbaik dalam menggunakan sumber daya yang terbatas untuk memaksimalkan dampak serangan.

Eksploitasi anak menunjuk pada sikap diskriminatif atau perlakuan sewenangwenang terhadap anak yang dilakukan oleh keluarga ataupun masyarakat. Memaksa anak untuk melakukan sesuatu demi kepentingan ekonomi, sosial ataupun politik tanpa memperhatikan hak-hak anak untuk mendapatkan perlindungan sesuai dengan perkembangan fisik, psikis \& status sosialnya. Eksploitasi anak menurut Suharto, F. A. (2014) adalah memanfaatkan anak secara tidak etis demi kebaikan ataupun keuntungan orang tua maupun orang lain. Eksploitasi fisik merupakan penyalahgunaan tenaga anak untuk dipekerjakan demi keuntungan orangtua atau orang lain seperti menyuruh anak bekerja dan menjuruskan anak pada pekerjaan-pekerjaan yang seharusnya belum dijalaninya.

UU No 39 tahun 1999 pasal 3, menekankan bahwa setiap orang dilahirkan dengan bebas, dengan harkat dan martabat yang sama dan sederajat, serta setiap orang berhak atas perlindungan dan kebebasan dasar manusia tanpa diskriminasi. Pasal 65 menyatakan bahwa setiap anak berhak untuk memperoleh perlindungan dari kegiatan eksploitasi dan pelecehan seksual, penculikan, perdagangan anak serta dari berbagai bentuk penyalahgunaan narkotika, psikotropika dan zat adiktif lainnya.

\section{Pandangan Islam Tentang Eksploitasi Anak}

Islam telah mengatur hubungan manusia dengan Allah SWT dan hubungan manusia dengan manusia serta hubungan manusia dengan alam, bahkan lebih jauh diatur 
tentang etika antar hubungan tersebut secara adil. Norma-norma yang dianut dalam Islam telah mengatur prinsip keadilan relasi, baik antara rakyat dengan negara, anak dengan orang tua, istri dengan suami ataupun buruh dengan majikan. Islam menolak segala bentuk tirani, eksploitasi, dominasi, dan hegemoni dalam berbagai aspek kehidupan, ekonomi, politik, budaya, dan gender. Hal ini ditegaskan dalam Al-Qur'an surah AnNisa'(4) ayat 58, yang artinya "Sesungguhnya Allah menyuruh kamu berlaku adil dan berbuat kebaikan, memberi kepada kerabat, dan Allah melarang kamu dari berbuat keji, kemungkaran, dan permusuhan. Dia memberi pengajaran kepada kamu agar kamu dapat mengambil pelajaran”. Al-Qur'an surah Al Nisa' (4) ayat 75, yang artinya "Mengapa kamu tidak mau berperang di jalan Allah dan (membela) orang-orang yang lemah baik laki-laki, perempuan-perempuan, dan anak-anakyang semuanya berdoa"ya Tuhan kami, keluarkanlah kami dari negeri inerli (Mekkah) yang zalim penduduknya dan berilah kami perlindungan dari sisi Engkau, dan berilah kami penolong dari sisi Engkau". "Hadits Qudsi, Riwayat Imam Muslim, yang artinya: Jadilah hamba-hamba Allah yang bersaudara satu dengan yang lainnya, karena seorang muslim itu saudara bagi muslim yang lain, tidak diperkenankan menzalimi, menipu, atau melecehkannya"(Kementrian Agama RI, 2011)

Thabathaba'i dalam Al-Mizan fiy Tafsir al-qur'an, Jus XIII dijelaskan bahwa Tuhan memuliakan manusia karena dalam dirinya terkandung sesuatu yang sangat istimewa, yaitu akal. Akal inilah yang menyebabkan manusia berbeda dengan makhluk lain, jika Allah SWT yang menciptakan manusia sangat menghormati, maka apalagi sesama manusia yang memang memiliki status dan kedudukan yang setara sebagai makhluk Tuhan. Al-Gazali, Al-Mustashf'a mim 'llm al-Ushul, Juz I, telah merumuskan dan menjelaskan tujuan syari'at Islam dengan lima prinsip perlindungan, yaitu; 1) perlindungan terhadap keyakinan agama, 2) perlindungan terhadap jiwa, 3) perlindungan terhadap akal pikiran, 4) perlindungan terhadap keturunan, dan 5) perlindungan terhadap harta benda. Setiap keputusan hukum yang mmengandung perlindungan terhadap lima hal ini adalah kemaslahatan dan setiap yang mengabaikannya adalah kerusakan, dan menolak kerusakan adalah kemaslahatan.

Islam memandang eksploitasi anak merupakan perbuatan yang bertentangan nilainilai eksistensi anak sebagai amanah yang harus pelihara, dijaga, dilindungi, diberikan kehidupan yang layak untuk masa depan yang baik. Beberapa ayat dalam Al Quran surah 
Al-Isra':31, yang artinya “Dan janganlah kamu membunuh anak-anakmu karena takut miskin. Kamilah yang memberi rezeki kepada mereka dan kepadamu, membunuh mereka itu sungguh suatu dosa yang besa. Membunuh anak yang dimaksud dalam ayat ini menurut Djaenab (2010, h.6) adalah bukan hanya membunuh keberlangsungan hidupnya tetapi lebih adalah membunuh masa depan yang suram. Eksploitasi tidak memberi kesempatan anak memperoleh ilmu, membunuh pengembangan kreativitas, perampasan hak anak karena faktor ekonomi dan sosial.

\section{Kota Layak Anak (KLA)}

Peraturan Pemerintah Kota Kendari Nomor 20 tahun 2013 Tentang Perlindungan Anak Kota Kendari dijelaskan bahwa Kota Layak Anak (KLA) merupakan pembangunan Kota/Kabupaten yang mengintegrasikan komitmen dan sumber daya pemerintah, masyarakat dan dunia usaha terencana secara menyeluruh dan berkelanjutan dalam kebijakan, program dan kegiatan untuk pemenuhan hak-hak anak. Substansi dari program Kota Layak Anak adalah terciptanya kota yang memberikan kesempatan anak untuk dapat tumbuh dan berkembang secara optimal serta terlindungi dari kekerasan dan diskriminasi. Desain dan indikator Kota Layak Anak di selaraskan dengan program dan Resolusi Majelis Umum PBB tanggal 10 Mei 2002 yang mengadopsi laporan Ad hoc pada sesi khusus anak yakni Sustainabel Development Goals (SDGs) pada tahun 2030. Artinya pemerintah masih mempunyai waktu kurang lebih 15 tahun untuk mewujudkan Child Friendly Country yang telah mendeklarasikan forum International "A World Fit For Children" tanggal 20 November 1989 di Amerika Serikat.

Klaster dan indikator Peraturan Menteri Negara Pemberdayaan Perempuan dan Perlindungan Anak Republik Indonesia nomor 12 tahun 2011 tentang indikator Kabupaten/Kota Layak Anak disesuaikan dengan Konvensi Hak Anak (KHA) dimana profil anak disesuaikan dengan progrma hak anak yang dituangkan dalam lima klaster Hak Anak, yaitu: 1) Hak sipil dan kebebasan, 2) lingkungan keluarga dan pengasuhan alternatif, 3) kesehatan dasar dan kesejahtraan, 4) pendidikan, pemanfaatan waktu luang dan kegiatan seni budaya, dan 5) perlindungan khusus (Lampiran Menteri PPPA No 13 th 2011).

\section{Hasil dan Pembahasan Penelitian}

\section{Bentuk Eksploitasi Terhadap Anak di Kota Kendari}


Ekploitasi anak terjadi hampir di seluruh nusantara, tidak terkecuali di kota Kendari. Meskipun kota Kendari sudah menjadi salah satu kota Kota yang Layak Anak di Indonesia, namun ekploitasi anak tetap terjadi dalam beberapa kelompok masyarakat tertentu di beberapa kelompok masyarakat. Hal ini berdasarkan hasil pengamatan dan wawancara di lapangan yang ditranskrip, "bahwa meskipun kota Kendari sudah termasuk Kota Layak Anak namun tidak bisa dihindari masih ada anak yang mengalami eksploitasi, baik yang dilakukan oleh keluarga/orang tua maupun pihak-pihak yang mengambil keuntungan dengan memanfaatkan keberadaan anak-anak dengan melakukan mobilsasi dengan menyuruh anak meminta uang dilampu merah, menjadi tukang pikul, mengelap/menyapu mobil, menjual tissu dan meminta sumbangan”.

Hasil pengamatan dan wawancara (tgl 5/1, 2020) dengan beberapa informan (orang tua) yang anaknya terpaksa bekerja membantu mencari nafkah untuk memenuhi biaya hidup keluarga, yang sudah dirangkum peneliti tetapi tidak menghilangkan substansi, sebagai berikut;

Hasil pengamatan peneliti di Mall Mandonga pasar basah dan Pelelangan ikan ditemukan bahwa anak tukang pikul sudah berada di lokasi pada pagi hari antara jam 6.00/7.00 sampai jam 10.00/11.00 terutama pada hari sabtu, minggu atau hari libur. Hal ini dikarenakan pada hari tersebut banyak pengunjung atau pembeli yang datang berpasar, sehingga mereka (anak-anak) dapat memperoleh penghasilan yang lebih banyak. Hal ini seperti ungkapan beberapa anak tukang pikul yang sudah akumulasi oleh peneliti, berikut:

(1) Saya (Adit 12 th) bekerja setiap hari mencari uang karena sudah tidak sekolah sedangkan adikku 4 orang, dua orang masih sekolah di SD dan ada yang masih kecil mau dibelikan susu, sedangkan mamaku tidak ada pekerjaannya di rumah saja memasak dan mengurus adikku, saya biasa mendapat uang upah memikul tiap hari 20.000-35.000 rupiah. Sedangkan bapak tiriku hanya buruh di pelabuhan dan kadang-kadang tukang becak atau kuli bangunan(Wawancara 7 Januari 2020). (2) La Ira 11 th) tinggal dengan nenekku sudah tua jadi saya bekerja cari uang untuk makan, biasanya saya selalu kelampu merah melap mobilnya orang, biasa juga menjula tissu, atau biasa juga menyanyi dengan temanku supaya bisa dapat uang. Bapakku mamaku tidak ada pergi merantau.

Eksploitasi anak di Kota Kendari yang dilakukan oleh orang tua dan preman pada pekerja anak seperti; menjadi pemulung, tukang pikul, penjula tissu, peminta/pengemis di lampu merah, penjajah makan ringan, dan menjadi buruh. Kondisi ini diperkuat oleh 
penjelasan staf Pemberdayaan Perempuan dan Perlindungan Ana Provinsi Sulawesi Tenggara (Gani 37 th) terungkap bahwa "salah satu yang menyebabkan masih terjadinya eksploitasi anak di Kota Kendari karena merupakan ibukota Provinsi dengan mobiltas masyarakat dari berbagai daerah baik yang berasal dari Kabupaten yang ada di Sulawesi Tenggara maupun dari luar daerah, (Wawancara 14 Februari 2020).

Kondisi ini tidak luput dari kehidupan anak-anak yang juga ikut bertarung menyambung kerasnya penghidupan. Anak-anak terpaksa harus berkerja meskipun usia mereka sebenarnya merupakan usia sekolah yang seharusnya duduk di bangku sekolah namun masalah ekonomi dan sosial yang dihadapi anak-anak menambah kemiskinan kultural yang tidak memiliki skill dan keterampilan mengakibatkan anak-anak hanya mampu melakukan pekerjaan yang instan untuk memperoleh uang. Mereka terpaksa harus bekerja karena sudah tidak sekolah jadi mereka membantu orang tua mencari uang untuk memenuhi kebutuhan hidup, seperti ungkapan informan melalui wawancara (5 Februari 2020):

"Saya (AT lk 12 tahun) tinggal di Alolama, saya tidak pernah bersekolah karena harus membantu orang tua bekerja mencari nafkan untuk membiayai adik-adikku. Saya biasa pergi memikul barang benaja ibu-ibu di pasar, biasa mengamen, biasa juga memulung. Sejak mamaku meninggal dunia bapakku sendirian yang mengurus kami. Saya anak pertama dan punya adik dua orang yang masih kecil. Pekerjaan bapakku hanya sebagai buruh dan biasa juga menjual sayur di pasar. Penghasilannya tidak cukup untuk biaya hidup kami jadi saya harus membantu bapakku bekerja mencari uang".

“(HN, Pr) 12 tahun tinggal dikampung baru, saya anak pertama ada adekku 2 orang ,tiap hari temani mamaku menjual sayur keliling dan membantu menjaga adekku. Saya juga biasa pergi sendiri menjal sayur kalau mamaku tidak bisa atau adekku sakit. Bapakku bekerja tukang mendorong lori-lori dipasar, uang penghasilan tidak bapakku sedikit tidak cukup untuk beli makan dan beli susu adekku. Saya dilarang sekolah mamaku karena tidak ada biaya. (AN, 9 thn) Saya tidak sekolah karena banyakji temanku yang tidak sekolah jadi saya ikut-ikut temanku pergi di pasar atau dilelang memikul barang jadi kita bisa dapat uang sendiri, saya tidak minta-mintami sama mamaku kalau beli jajan, saya kasimi juga mamaku separuh penghasilanku. Mamaku dan bapakku dia tidak marah kalau saya tidak sekolah. Kalau pulang di rumah saya main-main dengan teman-temanku".

Hasil temuan dapat disimpulkan bahwa akan sangat berpengaruh pada perkembangan mental dan sosialnya dan akan terganggu dikarenakan mereka mempunyai tanggung jawab yang harus dipenuhi sehingga mereka berupaya mencari dan mengumpulkan uang sebanyak-banyaknya, sekaligus mempengaruhi sosialnya yakni mereka harus bergaul dengan berbagai kalangan yang memaksa dia menjadi dewasa 
sebelum waktunya (anak-anak yang bersifat/berkarakter bagaikan orang dewasa) dikarenakan tugas dan tanggung jawab pada keluarga. Anak-anak yang bekerja seperti ini sangat rentang dengan kekerasan dan pelecehan seksual serta penyakit sosial.

Anak-anak yang bekerja sebahagian besar sesungguhnya bukan keinginan namun menjadi pilahan dikarenakan kondisi dan keadaan yang memaksa untuk menyambung hidup diri sendir dan keluarga. Mereka tidak memiliki pilihan meskipun menurut sebahagian orang dan aturan itu tidak boleh. Hal ini diperjelas oleh United Nations International Children's Emergency Fund (UNICEF) yang telah menetapkan beberapa kriteria eksploitasi terhadap anak yang bekerja antara lain; a) bekerja penuh waktu (full time) untuk umur yang terlalu dini, b) pekerjaan yang menimbulkan tekanan fisik, sosial, dan psikologis, c) upah yang tidak mencukupi, tanggung jawab yang terlalu banyak, d) pekerjaan yang menghambat ke akses pendidikan, e) pekerjaan yang mengurangi martabat dan harga diri anak, serta f) pekerjaan yang merusak perkembangan sosial dan psikologis. Sekretaris Dinas Pemberdayaan Perempuan dan Perlindungan Anak menjelaskan bahwa pemerintah sudah banyak memberikan dana bantuan pada anak-anak tidak mampu melalui Dina Pendidikan dan Kebudayaan, terutma bantuan sekolah seperti biaya membeli baju, sepatu, buku dan keperluan sekolah lannya. Diakui pula bahwa memang itu diberikan per triwulan dalam bentuk uang kess, jadi terkadang penggunaannya disalah gunakan orang tua untuk keperluan yang lain sehingga banyak anak-anak berhenti tidak sekolah.

Berikut data profil pekerja anak di Kota Kendari tahun 2017 yang disadur pada penelitian Ld Muhammad Elwan (2018), tentang jenis pekerjaan disektor jasa yang dilakukan oleh anak-anak di bahawa usia 18 tahun yang disajikan sebagai berikut:

Gambar1: Profil Pekerja Anak Kota Kendari tahun 2017 


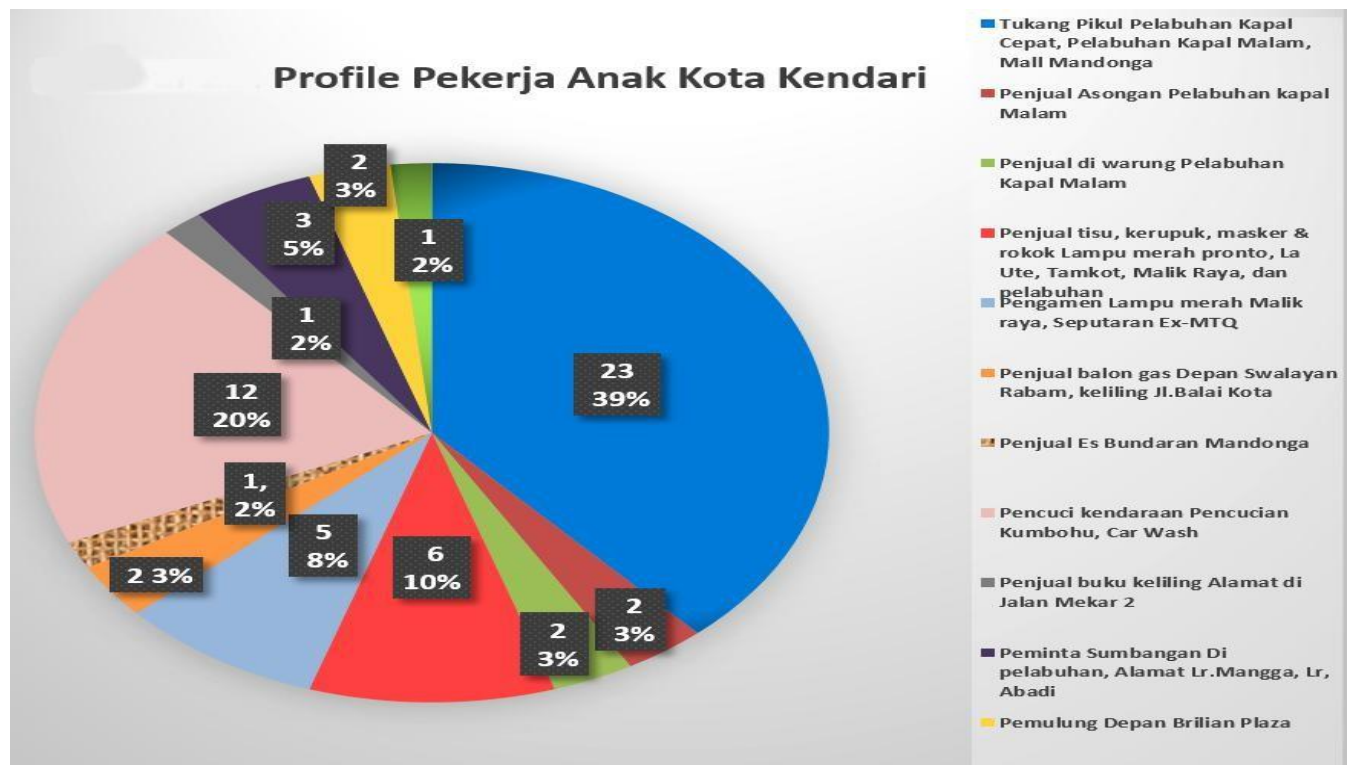

Sumber: Laporan Hasil Penelitian Kerjasama Bappeda Kota Kendari Th 2017

Keberadaan anak yang bekerja ini melanggar hak perlindungan dan tumbuh kembang anak. Menurut Tjandraningsih, I (2015, h.23) bahwa seharusnya pada usia tersebut, seharusnya anak masih menduduki bangku sekolah. Hal ini diperkuat oleh Tjandraningsih yang mengatakan bahwa ketika anak-anak tidak mempunyai kesempatan untuk bersekolah, maka pilihan hidupnya hanya dua, yaitu: masuk angkatan kerja atau tidak. Namun, perlu diingat bahwa anak-anak justru putus sekolah lantaran bekerja. Bahkan, di lingkungan yang kondusif untuk bekerja, konsekuensi yang muncul adalah gejala putus sekolah yang sering diawali dengan menggabungkan sekolah sambil bekerja.

Berikut kutipan wawancara dan pengamatan peneliti dengan beberapa informan yang berhenti sekolah untuk bekerja (7 Februari 2020), sebagai berikut:

(ARI) 13 thn menjelaskan bahwa "saya adalah anak satu-satunya dari bapak dan ibu yang masih hidup. Saya berhenti sekolah hanya kelas II karna mau cari uang untuk membantu orang tua, karena penghasilan bapakku (buruh bangunan) dan selalu sakit-sakit sedangkan mamaku tidak bekerja hanya di rumah saja, uang yang diperoeleh bapakku tiap hari tidak cukup beli makanan dan beli obat, tidak cukup untuk beli makan dan bayar lampu, air, kebutuhan hidup kami sehari-hari, kami tidak punya rumah hanya kontrak saja".

Ungkapkan informan di atas sejalan dengan data dalam diagram gambar1 tentang pekerja anak di kota Kendari yang berjumlah 39\% dri seluruh responden. Keterbatasan ekonomi memaksa anak bekerja membantu orang tua memenuhi kebutuhan hidup dan 
mengakibatkan sebahagian kecil anak harus putus atau berhenti sekolah. Kondisi ini seharusnya menjadi perhatian semua pihak, baik masyarakat, lembaga pemerhati terutama pemerintah, bahwa kenyataannyata kota kendari sebagai kota Metropolitan yang sarat dengan berbagai program mensejahtrakan rakyat ternyata masih ada segelintir orang terutama anak-anak yang hidup dalam serba kekurang dan ketertinggalan. Apabila ini ditangani secara baik maka akan memunculkan masalah-masalah sosial dan kemiskinan kultural yang berkelanjutan. Hasil temuan menunjukkan bahwa anak yang bekerja di kota Kendari sebahagian bukan penduduk asli, mereka ada yang datang pada saat tertentu seperti hari libur, atau hari raya, karena pada saat itu banyak pengunjung atau pembeli yang datang belanja terutama di pasar Basah Mall Mandonga. Anak-anak datang dari luar daerah hanya untuk sementara dan tinggal menumpang sama teman atau keluarga bahkan ada yang kos-kosan bersama dengan temannya sesama pendatang atau pencari kerja. Data anak yang bekerja di Kota Kendari sesungguhnya belum ada yang permanen namun data anak yang bekerja dan putus sekolah dapat dilihat berikut sesuai data yang disadur dari hasi penelitian Ld Muhammad Elwan tahun 2017, sebagi berikut:

\section{Gambar2: Pekerja Anak Yang Masih Sekolah Dan Putus Sekolah Thn 2017}

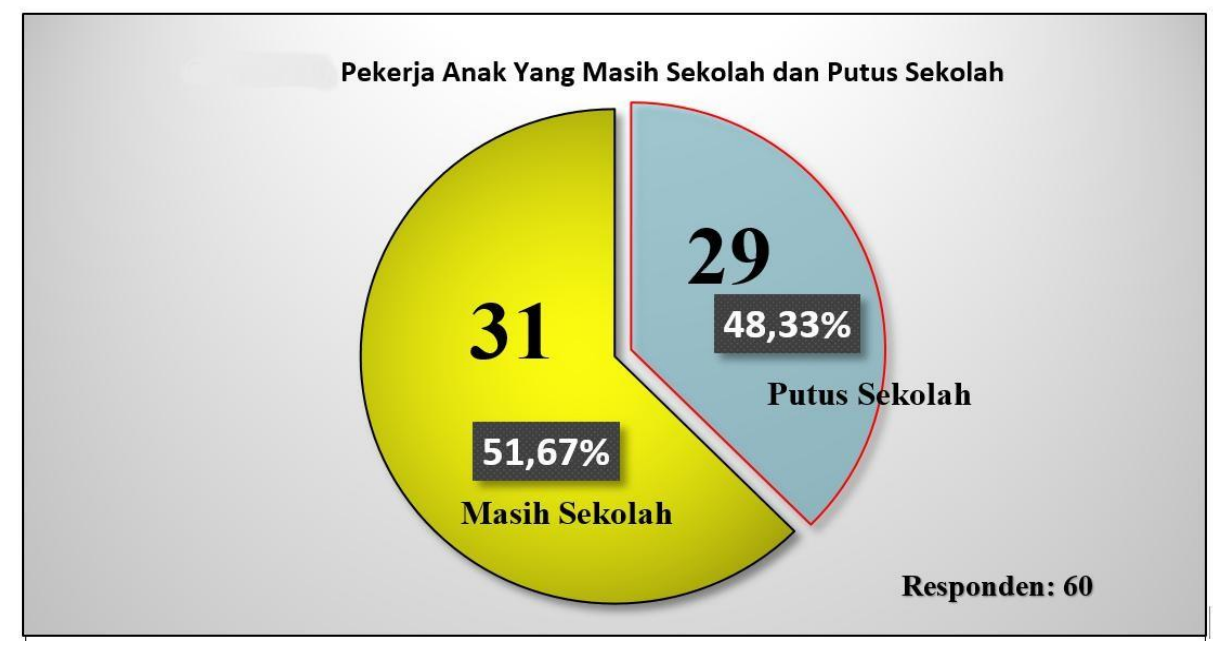

Sumber: Laporan Hasil Penelitian Kerjasama Bappeda Kota Kendari Thn 2017

Keluarga tidak mampu pada umumnya menjadikan anak mereka memiliki fungsi ekonomis, menjadi salah satu sumber pendapatan atau penghasilan keluarga, sehingga anak sudah terbiasa sejak usia dini dilatih dan dipersiapkan untuk menghasilkan uang dengan berbagai cara atau pekerjaan. Di Kota Kendari eksploitasi anak sangat beragam, 
bentuknya yakni anak-anak dijadikan sebagai; (1) kuli panggul atau tukang pikul, (2) pemulung, (3) pengemis, (4) pengamen, (5) mengelap mobil, dan (6) berjualan kue, tissu, dan jajanan lainnya. Dalam situasi dan kondisi sulit bahkan memberatkan semacam ini membuat orang tua dari tingkat ekonomi lemah ke bawah lebih memilih menjadikan anak-anak mereka sebagai penopang ekonomi kehidupan keluarga daripada bersekolah.

\section{Dampak Eksploitasi Anak Terhadap Kehidupan Anak}

Dampak dari ketimpangan ekonomi dan kemiskinan, mengakibatkan banyak keluarga melakukan eksploitasi pada anak mereka dengan memaksan anak-anak untuk bekerja membantu keluarga atau orang tua untuk mencari nafkah memenuhi kebutuhan hidup. Hasil observasi peneliti pada beberapa anak terungkap bahawa eksploitasi anak di Kota Kendari terutama berdampak pada:

1) Bidang ekonomi, sosial, kesehatan, psikologis dan pendidikan.

2) Anak putus sekolah, kenakalan, dan berkelahi.

3) Prilaku menyimpang secara sosial seperti; merokok, minum, menjudi, hidup bersama beberapa orang dengan laki-laki dan perempuan dalam satu kamar kontrakan.

4) Hidup, mereka tidak terawat tidak mengenal norma-norma budya dan nilai-nilai serta pengamalan agama.

Kasus kekerasan dan pelecehan terhadap anak, baik fisik maupun psikhis di Kota Kendari diakui oleh Kepala Seksi Perlindungan dan Kekerasan Anak bahwa masih adanya anak bekerja diberbagai tempat mengakibatkan terjadinya pelecehan dan kekerasan seksual yang dialami oleh beberapa anak. Sangat memprihatinkan kejadian kasus tersebut dilakukan oleh orang dewasa, bahkan ada yang dilakukan oleh keluarga dekat. Data Kementerian Sosial menyebutkan bahwa prevalensi kekerasan anak antara usia 13-17 tahun yaitu;

a) Kekerasan fisik pada anak laki-laki 1 dari 4 anak dan 1 dari 7 pada anak perempuan.

b) Kekerasan psikologis anak laki-laki 1 dari 8 anak dan anak perempuan 1:9.

c) Kekerasan seksual untuk anak laki-laki sebanyak 1:12 dan 1:19 untuk anak perempuan. 
Menurut Kepala Seksi Pemenuhan Hak Anak Bidang Sipil Informasi dan Partispasi PP\&PA bahwa di daerah saat ini pemenuhan hak anak pada sebahagian kecil anak masih jauh dari kata memadai. Dari pengawasan kebijakan anggaran di 9 (sembilan) provinsi pada tahun 2015, KPAI menemukan bahwa anggaran non-pemenuhan kebutuhan dasar untuk perlindungan anak hanya 1-2\% dari anggaran APBD di daerah, dan ini dianggap sangat tidak memadai, ditambah lagi koordinasi pelaksanakaan kegiatan tidak dilakukan secara bersinergi oleh OPD.

Temuan penelitian menunjukkan bahwa dampak yang terjadi bagi anak-anak yang bekerja di kota Kendari dibagi dalam tiga, yaitu; Dampak Pisik (Psiologis), Dampak Psikhis, Dan Dampak Sosial:

\section{Dampak Pisik (Psiologis)}

Berdasarkan temuan penelitian bahwa anak-anak yang bekerja sebagai kuli panggul perkembangan pisiknya terganggu, hal ini terlihat dari beberapa subjek, antara lain AR yang berusia 13 tahun bertubuh kurus, pucat dan kecil, pakaian yang dipakai juga lusuh. Setelah peneliti melakukan wawancara dia menjelaskan bahwa:

Saya RGG berusia 13 tahun setiap pagi jam lima atau jam enam pagi saya sudah berangkat ke pasar Mandonga jalan kaki dulu baru naik angkot karena rumah jauh masuk lorong. Saya belum makan (sarapan) di rumah kalau pagi, jadi nanti kalau saya sudah dapat uang baru saya belikan kue atau nasi kalau lapar saya tahan saja. Saya juga biasa saki atau demam atau pusing tapi saya tdk perduli karna biasanya sembuh sendiri. Kalau sakit jarang saya minum obat, tapi kalau ada obat bodreks atau paracetamol biasaji saya minum...... Itumi mungkin badanku kurus kecil. (Wawancara 8 Februaru 2020). Hal yang sama dilami oleh LBS berusia 13 tahun lebih, badannya (perawakannya) kekar, kakinya berbentuk $\mathrm{O}$, jalannya agak kangkang dan agak bungkung, tulang dadanya menonjol ke depan, lehernya pendek hampir tidak terlihat

\section{Dampak Psikhis (Psikhologis)}

Kehidupan anak-anak yang setiap hari bekerja di pasar atau di pelelangan ikan tidak memperhatikan kesehatan dan kebersihan. Kondisi tersebut mengakibat anak-anak menjadi sakit-sakitan dan mentalnya labil, beberapa dampak psikhis dari aspek kesehatan dapat muncul, sepertia penyakit gatal-gatal, flu dan pilek, batuk, sakit paru-paru, infeksi saluran pernapasan, kekurangan gizi, demam berdarah, hepatitis, diare dan lain-lain.

Kodisi ini dialami oleh anak-anak kuli panggul, pemulung, dan buruh dikapal oleh beberapa informan yang sudah ditranskrip dirangkum oleh peneliti, berikut:

"Kami AR (kembar), biasa sakit demam, filek dan batuk terutama kalau musim hujan, ini $\mathrm{k}$ arena kami kena hujan (kehujanan), terutama kalau hujan terus menerus, sementara kami harus tetap kerja mengangkat barang/belanjaan orang, padahal jalanan becek, kotor dan kotor, pada hal kami tidak memakai pengalas kaki (sandal). Kalau sudah pulang kerumah 
biasanya masuk angin jadi itulah penyebabnya kami saki (wawancara 10 Februari 2020). Kasusu lain dialami oleh RGG berusia11 tahun yang selalu menggaruk kulitnya. Setelah peneliti bertanya kenapa selalu menggaruk jawabannya bahwa dia sudah lama menderita penyakit gatal-gatal. Seluruh kulitnya terutama badan, kaki dan lengannya

Informasi dari orang tua mereka memperkuat ungkapan anak-anak di atas, bahwa anak-anak mereka ada yang tidak pernah diimunisasi, dan juga kalau sakit tidak pernah ke rumah sakit, alasannya mereka tidak punya waktu dan uang untuk membayar biaya dan ongkos ke puskesmas, belum lagi banyak pensyaratan yang diminta petugas.

\section{Dampak Sosial}

Bagi anak-anak yang bekerja di kota Kendari pengaruh lingkungan sosial sangat besar, hal ini disebabkan oleh karena waktu mereka lebih banyak di luar rumah dan bergaul bebas dengan teman-teman. Ditemukan bahwa secara umum dampak sosial yang terjadi pada anak-anak yang bekerja bersifat positif dan dampak negatif.

Dampak sosial yang positif dari hasil penelitian ditemukan bahwa lingkungan sosial yang bersifat positif adalah terlihat dari hubungan baik diantara anak-anak kuli panggul, saling menolong satu sama lain, kerja sama, tidak ada yang saling iri hati apabila ada yang memperoleh penghasilan lebih banyak, dan mereka saling mengenal dengan baik. Sikap kerja sama dan saling tolong meolong, bantu membantu terlihat ketika peneliti meminta tolong pada salah satu anak untuk mengumpulkan teman-temanya 20 orang di suatu tempat pada sore hari untuk bertemu dengan peneliti dan melakukan wawancara. Hasil pengamatan di atas diperkuat oleh wawancara dengan beberapa anak-anak kuli panggul sebagai berikut:

"Kami anak-anak yang bekerja sebagai tukang pikul selalu saling membantu satu sama lain, kami biasa membantu teman membawakan pikulannya kalau ada yang kurang sehat atau bawaannya/pikulannya berat. Kami juga memanggil teman-teman yang belum mendapat pekerjaan kalau ada ibu-ibu yang mencari anak untuk memikul/mengangkat barangnya".

Ungkapan lain disampaikan oleh salah seorang informan;

"bahwa kami selalu berbagai dengan teman-teman sesama anak-anak kuli panggul (tukang pikul) seperti kalau kami punya makanan atau ada yang memberikan makanan kami selalu berbagi biar hanya dapat sedikit-sedikit setiap orang" (wawancara 5 Februari 2020).

Selain itu dampak lingkungan sosial yang bersifat negatif juga berpengaruh pada kepribadian dan prilaku mereka. Hal ini terlihat dari hasil pengamatan peneliti dan informasi dari beberapa anak bahwa prilaku anak-anak terlihat bermacam-macam seperti 
ada anak yang berkelahi, saling menegjek, merokok, menghisap lem fox, berkelah, minum-minuman keras, berkata-kata kasar dan jorok (anak bule, tailaso, setan, anjing, dan lain-lain) berpakaian seronok, pake anting-anting (asesoris yang belebihan), adapula yang berprilaku ganda (laki-laki seperti perempuan).

Informasi dari masyarakat sekitar Mandonga (Ibu Dewi) menjelaskan bahwa anak-anak kuli panggul memang tidak selalu membuat keributan di sekitar tempat tinggalnya, tapi kita tidak tahu apa saja yang mereka kerjakan, karena mereka pergi pagi kadang-kadang malam baru pulang. Mereka tinggal bersama dengan menyewa satu kamar, mereka tinggal bersama dengan 5-8 orang. Mereka memang menjadikan kostkosannya hanya sebagai tempat persinggahan sementara karena mereka hanya datang sebentar lalu kemudian pergi lagi. Waktu mereka lebih banyak di jalan atau berkumpul dengan teman-teman dimana saja. Hal ini terjadi terutama bagi anak-anak yang hanya datang di kendari untuk bekerja mencari uang. Mereka sebahagian ada yang berasal dari luar kota kendari, seperti dari Raha (Muna), Buton, Konawe, Konawe Selatan, Konawe Utara,dan dari daerah lain yang masih wilayah SulawesiTenggara.

Ki Hadjar Dewantara (N. Yohana; 2017) menegaskan bahwa keluarga adalah suatu tempat yang sebaik-baiknya untuk melakukan pendidikan sosial. Keluarga adalah tempat pendidikan yang lebih sempurna sifat dan wujudnya dari pada pusat-pusat lainnya untuk melangsungkan pendidikan kearah kecerdasan budi pekerti (pembentukan watak individual) dan sebagai persediaan hidup kemasyarakatan. Dalam Al-Qur'an surah AnNisaa:9, mengingatkan bahwa bahwa:

"Dan hendaklah takut kepada Allah orang-orang yang seandainya meninggalkan dibelakang mereka anak-anak yang lemah, yang mereka khawatir terhadap (kesejahtraan dan prilaku) mereka. Oleh sebab itu hendaklah mereka mengucapkan perkataan yang benar".

\section{Upaya Pemerintah Mencegah Eksploitasi Anak Sebagai Kota Layak Anak}

Wilayah administrasi kota Kendari terdiri atas 10 wilayah Kecamatan, yaitu Kecamatan Mandonga, kecamatan Kadia, kecamatan Baruga, kecamatan Puuwatu, kecamatan Wua-wua, kecamatan Poasia, kecamatan Abeli, kecamatan Kambu, kecamatan Kendari, kecamatan Kendari Barat, berdasarkan Peraturan Daerah kota Kendari nomor 15 s/d 14 tahun 2005, dan terbagi dalam 64 Kelurahan. Penduduk kota Kendari berdasarkan sensus penduduk tahun 2017, pada tahun 2013 dihuni oleh jumlah 
penduduk 359.371 jiwa, dengan rincian laki-laki berjumlah 158.599 dan perempuan berjumlah 155.527. Agama yang dianut Islam, Kristen, Katolik, Buudha, Hindu, Kongchu, Persebaran penduduk tidak merata di setiap Kecamatan dan Kelurahan. Kecamatan terbesar penduduknnya adalah Kendari Barat, yang sekaligus lebih padat dan paling tinggi jumlah penduduknya yakni 6.336 jiwa per $\mathrm{km}^{2}$, sedangkan Kecamatan Baruga adalah yang paling rendahn yakni 437 jiwa per $\mathrm{km}^{2}$.

Program pemerintah melalui program yang terdapat dalam Kementrian Pemberdayaan Perempuan dan Perlindungan anak yang sekarang sedang digalakkan adalah Kabupaten/Kota Layak anak (KLA). Menurut Kepala Seksi Pemenuhan Hak Anak Bidang Sipil Informasi dan Partispasi Dinas Pemberdayaan Perempuan dan Perlindungan Anak (Mely Damayanti, 2020) Kota Kendari, bahwa; untuk mewujudkan program Kota Layak Anak harus ada penyadaran tanggung jawab semua pihak terutama OPD yang terkait lebuh maksimal dan memiliki program yang jelas dan skala prioritas mewujudkan Kota Layak Anak. Ditempat terpisah Kepala Bidang Perlindungan Hak Anak Kota Kendari menjelaskan bahwa:

"Lahirnya kebijakan Kota Layak Anak diharapkan dapat menciptakan keluarga yang sayang anak, rukun tetangga, dan rukun warga, lingkungan yang peduli anak. Pemerintah berupaya memastikan bahwa anak-anak tumbuh dan berkembang dengan baik, terlindungi haknya dan terpenuhi kebutuhan pisik dan psikologisnya (Wawancara 17 januari 2020). Selanjutnya dijelaskan bahwa Kota Layak Anak sebagai program pemerintah yang dilaksanakan masing Organisasi Perangkat Daerah (OPD) se Kota Kendari, bertujuan untuk mewujudkan Kota Layak Anak dan pemerintah telah melakukan berbagai upaya mengintergrasikan isu-isu perlindungan anak dan pemenuhan hak anak dalam dokumen perencanaan pembangunan, hal ini dilakukan untuk mempercepat terwujudnya Kota menjadi daerah yang layak anak".

Dijelaskan oleh Sekretaris Dinas PP\&PA Kota Kendari bahwa untuk mendukung pelaksanaan program KLA, Pemerintah Daerah harus memastikan terpenuhinya hak anak untuk didengarkan secara penuh, maka dalam setiap tahapan pengembangan Kota Layak Anak, akan dilakukan langkah-langkah sesuai dengan peraturana pemerintah sebagai berikut: Berikut penjelasan Sekretaris Pemberdayaan dan Perlindungan Anak kota Kendari dalam mewujudkan Kota Layak Anak di Kendari, bahwa:

"Sangat dibutuhkan kerja sama antara pemerintah dan seluruh stekcholder terutama masyarakat. Pelaksanaan kota layak anak sebenarnya sudah dilaksanakan oleh masingmasing Organisasi Perangkat Daerah, karena memang Dinas Pemberdayaan Perempuan dan Perlindungan Anak hanya sebagai koordinator, pelekasanaan dan anggaran dengan 
mekansime KLA sepenuhnya dilaksanakan oleh masing-masing OPD, kami hanya membantu apabila dibutuhkan. Sebetulnya kami juga memang mempunya program tersendiri tetapi lebih banyak adalah membantu dan menyelesaikan masalah-masalah dan kasus-kasus yang dialami oleh perempuan dan anak, misalnya perempuan dan anak yang mengalami kekerasan, pelecehan, diskriminasi dan atau masalah keluarga (dr $\mathrm{Hj}$. Asrida Mukaddim, 2020).

Diungkapkan pula bahwa ada beberapa kebijakan yang harus dilakukan oleh Pemerintah Daerah sebagai upaya untuk mencapai indikator bidang perlindungan anak berwujud KLA, antara lain; a) membentuk komite aksi penghapusan pekerja terburuk bagi anak, b) memantau dan melakukan penertiban di tempat umum, c) melakukan kegiatan pembinaan, pelatihan kerja. Kegiatan sosialisasi pada anak-anak terutama yang melakukan pekerjaan sperti; kuli panggul, pengamen, penjual, pemulung, dan lain-lain. Hal tersebut dikemukakan oleh salah seorang staf Nakertrans Kota Kendari bahwa:
"Anak-anak jalanan dan kuli panggul merupakan objek yang mudah direkrut dan dipengaruhi oleh oknum-oknum tertentu untuk dijadikan pengedar maupun pengguna narkoba. oleh karena itu, pemerintah kota Kendari melalui Dinas Sosial Naketrans menyelenggarakan sosialisasi pencegahan penyalahgunaan narkoba kepada mereka. Harapan kami adalah, melalui kegiatan tersebut, anak-anak dapat mengetahui jenis-jenis obat yang termasuk ke dalam narkoba, bahaya yang dapat ditimbulkan dari narkoba serta bagaimana cara mereka agar bisa menghindari narkoba (Winartilsmail Ismail, 2020).

Anak merupakan amanah dan karunia Allah SWT, Tuhan Yang Maha Esa, diciptakan dan memiliki hak hidup bersama makhluk lain di muka bumi. Anak memiliki harkat dan martabat serta potensi sebagai generasi penerus bangsa dan agama, mereka berhak memperoleh perlindungan dan kesempatan untuk hidup dan mendapatkan kehidupan yang layak. Undang Undang Dasar 1945 pasal 27 ayat 2, tegas menjelaskan bahwa "tiap-tiap warganegara berhak atas pekerjaan dan penghidupan yang layak bagi kemanusiaan". Anak sebagai individu merupakan bagian dari masyarakat yang memiliki hak hidup sama dengan orang dewasa. Mereka tumbuh dan berkembang dengan bantuan, bimbingan dan pendidikan dari orang dewasa. Pertumbuhan dan perkembangan dipengaruh oleh lingkungan keluarga, sekolah dan masyarakat, sikap dan karakter anak tercermin dari warna yang diberikan sejak masih kecil (Machmud H, 2010, h.168).

Peletakan nilai, norma dan dasar pada anak yang dianut dalam suatu keluarga, kelompok atau masyarakat merupakan suatu keniscayaan, hal ini dikarenakan anak mengimitasi semua hal dari lingkungan dia berada. Anak lahir dalam keadaan fitrah atau 
suci/putih, hal ini dijelaskan dalam Hadits bahwa "Setiap Manusia (anak) lahir dalam keadaan suci kedua orang tuanyalah yang menjadikan dia Majusi, Yahudi atau Nasarani”. Hadis ini diperkuat oleh teori John Lock yang menegaskan bahwa anak lahir bagaikan kertas putih, lingkunganlah yang memberikan warna terutama keluarga. Keluarga atau orang tua sebagai peletak dasar nilai-nilai, norma-norma budaya kehidupan dituntut untuk mempersiapkan mereka dengan pengetahuan, keterampilan, dan kemampuan untuk mengarungi kehidupan selanjutnya.

\section{Penutup}

Anak merupakan tunas muda penerus cita-cita perjuangan bangsa, memiliki peran strategis dan membutuhkan kesempatan seluas-luasnya untuk tumbuh dan berkembang secara optimal, baik fisik, mental, sosial dan berakhlak mulia. Ekonomi keluarga yang rendah, kemiskinan, keterbelakangan komunitas, pengaruh lingkungan, keretakan, kekerasan kehidupan rumah tangga, dan perceraian orang tua, menyebabkan sebahagian kecil anak harus merjibaku melakukan berbagai pekerjaan untuk dapat memperoleh uang untuk bertahan hidup bersama keluarga. Eksploitasi orang tua terhadap anak-anaknya karena tidak memahami kehidupan dunia anak, bahkan dapat merusak jiwa dan masa depan mereka bahan melanggar aturan hukum yang ada.

Islam lahir sebagai agama yang menghargai hak-hak setiap orang menghapus perbudakan, diskriminasi, kekerasan, eksploitasi dan dekadensi moral. Islam mengharuskan untuk tidak meninggalkan generasi yang lemah; (a) lemah secara ekonomi, (b) lemah fisik, Rasulullah SAW bersabda "didiklah anak-anakmu untuk berenang, melempar dan berkuda" Rasulullah mengingatkan bahwa mukmin yang kuat lebih baik dan dicintai Allah dari pada mukmin yang lemah. (c) lemah ilmu, begitu pentingnya ilmu bagi manusia sehingga Allah SWT ketika memberikan wahyu pertama pada Muhammad Rasulullah SAW adalah iqro (bacalah) atau berilmulah. Demikian pula ketika Allah SWT pertama mengajarkan ilmu pada nabi Adam AS tentang nama-nama benda di bumi, dan (d) lemah akidah, inilah kelemahan yang paling dahsyat bahaya sehingga Allah mengingatkan dalam surah At-Tahrim ayat 6 "Hai orang-orang yang beriman peliharalah dirimu dan keluargamu dari api neraka........ (Kementrian Agama RI, 2002). 
Hasil penelitian 20 orang anak yang bekerja membantu keluarga mencari nafkah untuk kebutuhan hidup. Sebagian dari mereka tinggal bersama orang tua, nenek, paman (kerabat) dan ada pula yang mengontrak kamar diantar mereka tidak lagi bersekolah (putus sekolah), dan ada yang masih bersekolah di sore hari. Pergaulan mereka tidak beraturan, bebas melakukan sesuatu yang diinginkan tanpa ada orang lain yang membatasi, terkadang mereka melakukan hal-hal yang hanya boleh dilakukan oleh orang dewasa seperti merokok, minum-minuman keras, main judi, narkoba, berkelahi, dan lainlain. Tidak ada waktu untuk mempelajari agama, etika, moral dan adat istiadat budaya. Kondisi anak-anak seperti ini apabila tidak ditangani secara efektif, maka 10-15 tahun yang akan datang akan menjadi beban negara dan masyarakat. Mereka tidak dapat berkompetisi dan akan menjadi tenaga kerja yang tidak produktif, bahkan kemungkinan besar akan menjadi beban dan musuh negara serta masyarakat dengan melakukan pekerjaan atau kegiatan yang melawan hukum.

\section{DAFTAR PUSTAKA}

Adams, S., \& Savahl, S. (2017). Nature as children's space: A systematic review. The Journal of Environmental Education, 48(5), 291-321. doi:10.1080/00958964.2017.1366160

Al-Gazali, Al-Mustashf'a mim 'llm al-Ushul, Juz I. (Beirut:Dar Ihya' at-Tur'ats alArabi),

Allsup, R., Thomas, E., Monk, B., Frank, R., \& Bouchard, M. (2015). Networking in Child Exploitation. Proceedings of the 2015 IEEE/ACM International Conference on Advances in Social Networks Analysis and Mining 2015 - ASONAM '15. doi: $10.1145 / 2808797.2809297 .400$

Antara News; 24 Juli (2019)

Andriani Elizabeth, Zainul Hidayat. (2008). Implementasi program kota layak anak dalam upaya pemenuhan kebutuhan hak-hak anak dikota bekasi. Undip. https://media.neliti.com

Badan Pusat Statistik.( 2018). Kota Kendari dalam Angka 2018.

Beta Septi Iryani. (2013). Eksploitasi terhadap Anak yang Bekerja di Indonesia. Jurnal Ekonomi dan Pembanguan Indonesia. 13(2).

Boby Novika. (2018). Optimalisasi Pelaksanaan Kebijakan Pengembangan Kota Layak Anak dan Implementasinya Terhadap Ketahanan Sosial Masyarakat. Jurnal Ketahanan Nasional. https://jurnal.ugm.ac.id. 
Darmini Roza dan Laurensius Arliman S Peran. (2018). Pemerintah Daerah dalam mewujudkan Kota Layak Anak di Indonesia. https;//ejournal.undip.ac.id.

Djaenab. (2010). Perlindungan Anak Persfektif Fiqhi dan Perundang-undangan. Jurnal al-Risalah, Volume 10.

Hadi Machmud. (2010). Psikologi Perkembangan, Kendari: CV.Shadra.

Imran Jauhari. (2013). Perbandingan Sistim Hukum Perlindungan Anak Antar Indonesia dan Malaysia, Artikel Jurnal Asy-Syir'ah, Vol. 47, 2.

Indrasari Tjandraningsih \& Popon Anarita. (2002). Pekerja Anak di Perkebunan Tembakau. https://catalogue.nila.gov.au.

KPAI, (2018). "Membangun Sistem Perlindungan Anak", http://www.kpai.go.id/berita/membangun-sistem-perlindungan-anak-2/, diakses tanggal 10 Januari 2018.

Kementerian Perempuan dan Perlindungan Anak. (2018). Membangun Kepedulian Masyarakat dalam Upaya Perlindungan Anak. https://www.kemenpppa.go.id/index.php/page/read/30/427/menteri-yohanamembangun-kepedulian-masyarakat-dalam-upaya-perlindungan-anak, diakses tanggal 10 Januari 2018.

Kementerian Agama RI. (2011) Al Qur'an dan Terjemahan

Lampiran Peraturan Menteri Negara Pemberdayaan Perempuan Dan Perlindungan Anak RepublikIndonesia Nomor 13 Tahun 2011 tentang Panduan Pengembangan Kabupaten/Kota Layak Anak.

La Ode Muhammad Elwan. (2018). Rekomendasi Kebijakan Kota Layak Anak di Kota Kendari. Publication Faculty Of Social and Political Sciences Halu Oleo University, Vol.2.No.1. April 2018, diakses 21 Februari 2020.

Leonard Swidler \& Paul Mojzes. (2000). The Study of Religion in an Age Global Dialogue, (Philadelphia:Temple University Press.

Maidin Gultom. (2008). Perlindungan Hukum terhadap Anak dalam Sistem Peradilan Pidana Anak di Indonesia. Bndung: Refika Aditama.

Misoska, A. T. (2013). Giving children space to express themselves: exploring children's views and perspectives of contact programmes in Northern Ireland and the Republic of Macedonia. Compare: A Journal of Comparative and International Education, 44(5), 778-800. doi:10.1080/03057925.2013.792665

Murnaghan, A. M. F., \& Basu, R. (2016). Playfully Negotiating Publics: Children, Space, and Activism in the City. Spatial Diversity and Dynamics in Resources and Urban Development, 517-525. doi:10.1007/978-94-017-9786-3_25

Nenik Yuniarti. (2012). Eksploitasi Anak Jalanan Sebagai Pengamen dan Pengemis di Terminal Tidar oleh Keluarga. International Journal Of Indonesian Society and Culture. Vol.2.

Neni Yohana. (2017). Konsep Pendidikan dalam Keluarga Menurut Pemikiran Ki Hadjar Dwantara dan Hasan Langgulung. OASIS: Jurnal Ilmiah Kajian Islam, 2(1). 
Nuraeny, H. (2017). Child Exploitation As A Phenomenon Of Human Trafficking. Journal of Engineering and Applied Sciences, 12(18), 4661-4666. doi: 10.3923/jeasci.2017.4661.4666

Rita Pranawati. (2018). Membangun Sistem Perlindungan Anak. https://nasional.sindonews.com/read/1222963/18/membangun-sistemperlindungan-anak-1500694077, diakses tanggal 10 Maret 2018.

Saeful Salih \& Muhammad Nur. (2016). Eksploitasi Pekerja Anak Pemulung. Jurnal Equelibirium Pendidikan Sosiologi. Vol.IV(1).

Suharto, F. A. (2014). Eksploitasi anak. (online), (http://anggunfatmawati.blogspot.com/2014/10/makalaheksploitasianakhtml, diakses tanggal 19 oktober 2014).

Tjandraningsih, I. (2015). Pemberdayaan Pekerja Anak: Studi Mengenai Pendampingan Pekerja Anak. Bandung: AKATIG.

Undang-Undang No. 23 Tahun. (2002). Tentang Perlindungan Anak.

Usman, H. \& Nachrowi, D. N. (20..). Pekerja Anak di Indonesia: Kondisi, Determinan, dan Eks- ploitasi (Kajian kuantitatif). (Jakarta: Grasindo.

Peraturan Menteri Negara Pemberdayaan Perempuan dan Perlindungan Anak No. 11 Tahun 2011 Tentang Kebijakan Pengembangan Kabupaten/Kota Layak Anak.

Peraturan Menteri Negara Pemberdayaan Perempuan dan Perlindungan Anak Republik Indonesia No. 12 Tahun 2011 Tentang Indikator Kabupaten/Kota Layak Anak, Pojok ASI dan Fasilitas Menyusui.

Peraturan Daerah Kota Kendari No 12 Tahun 2013 Tentang Penyelenggaraan Perlindungan Anak Kota Kendari.

Peraturan Pemerintah Kota Kendari Nomor 20 tahun 2013 Tentang Perlindungan Anak Kota Kendari.

Tjandraningsih.I. dkk.2010. Pemberdayaan Pekerja Anak:Studi Mengenai Pendampngan Pekerja Anak. Junal PKS vol 15(3).

Yohana Susana Yembise. (2017). "Jadikan Kota Layak Anak Untuk Cegah Kekerasan", http://kompas.com/read/2015/11/07/201353023/Jadikan.Kota.Layak.Anak.untuk .C egah.Kekerasan, tanggal 7 November 2015 .

Van Buggenhout, M. (2019). Street child spaces: belonging, conflict and resistance in the city of Durban through the eyes of street youth. Children's Geographies, 1-14. doi:10.1080/14733285.2019.1668911. 